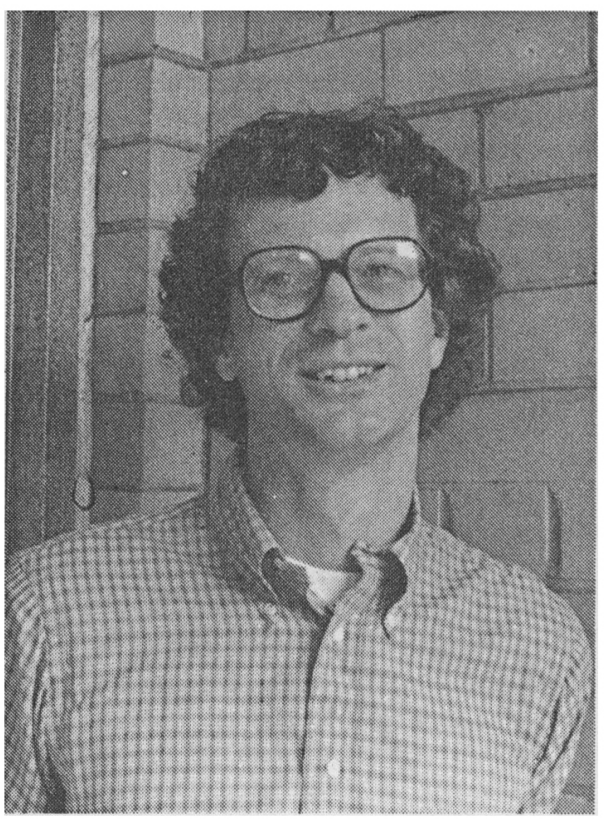

Christopher Deering of Georgetown University has been appointed director of academic program and planning of the APSA Congressional Fellowship Program.

\section{Political Scientists and Journalists Named Congressional Fellows}

The APSA has announced the winners in the national competition for the 1989-90 Congressional Fellowship Program. Following a one-month orientation beginning in November, Fellows spend nine months working as legislative aides in congressional offices.

The new political science and journalism Fellows are:

\section{Political Science Fellows}

Christopher Bailey, Department of American Studies, University of Keele, Staffordshire, England.

Paul Herrnson, Department of Political Science, University of Massachusetts, Amherst.
Janet Martin, Department of Government and Legal Studies, Bowdoin College, Brunswick, Maine.

\section{Journalism Fellows}

Kristin Huckshorn, San Jose Mercury News, San Jose, California.

Philip Ingrassia, KDLT.TV, Sioux Falls, South Dakota. (Mr. Ingrassia is the fourth recipient of the annual Joan Shorenstein Barone Congressional Fellowship in Broadcast Journalism.)

Lisa Pullen, The Charlotte Observer, Charlotte, North Carolina.

Stephen Ward, Michigan Public Radio Network, Lansing, Michigan.

Sponsored by the Association since 1953, the purpose of the Congressional Fellowship Program is to give outstanding political scientists, journalists, medical faculty, and federal agency executives an opportunity to acquire a rich understanding of the national legislative process.

The Selection Committee was composed of Roger Davidson of the University of Maryland, Christopher Deering of the George Washington University, Ronald D. Elving of Congressional Quarterly Weekly Report, Susan Hammond of American University, Albert R. Hunt of Wall Street journal, and Carol Matlack of National Journal.

The over 1,300 alumni of the program include university presidents, deans, and professors, newspaper and magazine publishers, editors and reporters; senior-level executives in the federal government, and members of Congress and congressional staff aides.

Other participants in the $1989-90$ program will include:

\section{Carl Albert Fellow}

Kenneth M. Cosgrove, B.A. Political Science, Suffolk University, Boston; Ph.D. Candidate, University of Oklahoma.

\section{Asian Fellows}

Changsu Kim, Senior Researcher, Policy Planning Directorate, Korea Institute for Defense Analysis, Seoul, South Korea.

Raja A. Nazrin, Assistant Secretary, Commonwealth Heads of Government Meeting, Foreign Ministry, Government of Malaysia.

Smita Notosusanto, Faculty of Social and Polit- 
ical Sciences, Department of International Relations, University of Indonesia.

Mohammad Ziauddin, Director, Foreign Minister's Office. Ministry of Foreign Affairs, Government of Bangladesh.

\section{French Fellow}

Emmanuele d'Achon, Economic Desk Officer for North America, French Ministry of Foreign Affairs.

\section{West German Fellows}

Wolfgang J. M. Drechsler, University Lecturer in American Studies, Philipps-Universitat Marburg

Peter Muller, Adviser in the Akademisches Auslandsamt of the University of Freiburg; Ph.D. Candidate

\section{American Society of \\ Allied Health Professions (Kellogg Health Policy Fellow)}

Marcia K. Brand, Special Assistant to the Dean and Coordinator, Career Services Center, College of Allied Health Sciences, Thomas Jefferson University.

American Anthropological Association Fellows

Lesely Gill, Ph.D., Anthropology, Columbia University, New York, Fulbright Research Fellow.

Jo Anne Schneider, Ph.D., Anthropology, Tempie University, Philadelphia, Adjunct Assistant Professor, Anthropology Department.

\section{Health Policy Fellows}

Benjamin Chu, M.D., Assistant Professor, Department of Medicine, Kings County Hospital, Brooklyn, New York.

Philip H. Goodman, M.D., M.S., Associate Professor of Medicine, University of Nevada, Veterans Administration Medical Center, Reno.

Melvin D. Shipp, O.D., M.P.H., Associate Professor, School of Optometry/The Medical Center, University of Alabama at Birmingham.

Danny Wedding, Ph.D., Professor of Medical Psychology, Department of Psychiatry, School of Medicine, Marshall University, Huntington, W. Va.

Earnestine Willis, M.D., M.P.H., Associate Professor of Clinical Pediatrics, University of Chicago, Woodlawn Maternal and Child Health Center, Chicago.
Edward T. Wimberly, Ph.D., Director, Department of Social Work, Assistant Professor, Department of Preventive Medicine and Community Health, The University of Texas at Galveston.

\section{Federal Fellows}

Susan 1. Clain, Senior Legislative Specialist, Health Care Financing Administration, Office of Legislation and Policy, Department of Health and Human Resources.

Lyn Creswell, Major, Land Use Planning Officer, Marine Corps, Department of the Navy.

Bernand T. Devaney, Senior Intelligence Operations Specialist for Middle East/Africa Division, Defense Intelligence Agency.

Loren Ford, Biological Scientist, Agency for International Development in the Caribbean, Forest Service, Department of Agriculture.

David C. Gustafson, Manager of Actuarial Policy Division, Corporate Policy and Research Department, Pension Benefit Guaranty Corporation.

Marjorie W. Holmes, Chief, Marketing Branch, Information Services Division, Office of Information Resources, Central Intelligence Agency.

Bruce E. Kasold, Major, Assistant to the General Council, Office of the Secretary of the Army.

Janice Dunn Lee, Special Assistant to the Chairman for International and State Programs, Nuclear Regulatory Commission.

Denise M. Leger-Lee, Personnel Management Specialist, Classification, Staffing and Compensation, Human Resources Division, Department of Agriculture.

Aubrey D. McElhaney, Program Analyst, Office of Ocean Services, Department of Commerce.

Mary C. Rubin, Employment Advisor, President's Committee on Employment of People With Disabilities, Department of Labor.

John B. Snowden, Branch Chief, National Security Agency.

Michael E: Talbert, Branch Chief, Employment Standards Administration, Department of Labor.

Barry Zalcman, Technical Assistant to the Associate Director for Special Projects, Nuclear Regulatory Commission.

\section{Foreign Affairs Fellows}

Sharon L. Basso, Deputy Chief, Media Relations, Public Affairs Office, Central Intelligence Agency. 
Janey D. Cole, Country Affairs Officer, Andean Region of Latin America, United States Information Agency.

Jerry A. DeMoney, Lieutenant Colonel, Military Intelligence, Department of the Army.

David P. Fichtner, Analyst, Command and Operations Branch of the Theater Forces Division, Regional Issues Group, Office of Soviet Analysis, Central Intelligence Agency.

Bruce N. Gray, Chief, Visa Section, American Consulate General, Hong Kong.

Leslie S. Hart, Chief, Division of Cultural Resources, Alaska Regional Office, National Park Service, Department of the Interior.

John F. Johnson, Major, Operations Officer, Military Intelligence, Department of the Army.

Eric Lief, Foreign Service Officer, Special Assistant to the Comptroller, Department of State.

Raymond J. Pardon, Regional Labor Officer for Southern Africa, American Consulate General, Johannesburg.

Stephen J. Tomchik, Special Assistant to the Under Secretary of State for Political Affairs, Department of State.

Kaarn J. Weaver, Chief, Political/Economic Section, American Consulate General, Hong Kong.

\section{German APSA Congressional Fellows Hold Reunion}

\section{Claus Gramckow}

APSA Congressional Fellowships for foreign professionals are available through special arrangements between APSA and international foundations. Since 1982, two West German scholars of American Government have received fellowship support from the German Marshall Fund of the United States and the John J. MeCloy Fund of the American Council on Germany.

In June of this year, former APSA Congressional Fellows from The Federal Republic of Germany held a reunion at the University Club of the Free University of Berlin. Fourteen former fellows attended the reunion organized by Eberhard Barg (Fellow, 1983-84) and Stefan von Senger (Fellow, 1987-88). The former fellows were joined by members of the fellowship selection committee: Prof. Dr. Ernst Otto Czempiel of the Hessische Stiftung for

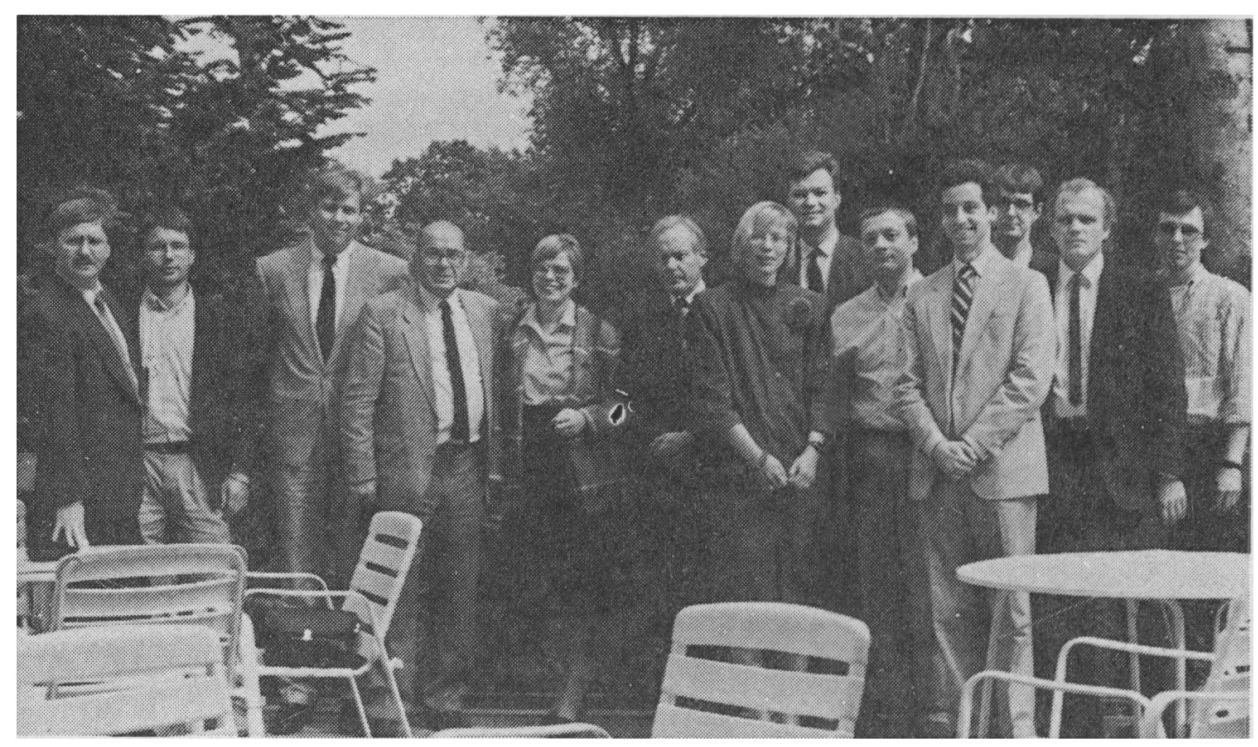

Participants in the West German Congressional Fellowship reunion (l. to r.): Eberhard Barg, Dr. Peter Rudolph, Klaus Frankenberger, Prof. Dr. Kurt L. Shell, Prof. Dr. Helga Haftendorn, Prof. Dr. Ernst Otto Czempiel, Dr. Armgard von Reden, Thorsten Hutter, Dr. Werner Jann, Stefan von Senger, Dr. Juergen Wilzewski, Claus Gramckow, and Dr. Joerg Boltersdorf. 